\title{
Identifikasi Escherichia coli yang Resistan Antibiotik pada Daging Burger yang Dijual di Sekitar Kampus IPB Dramaga Bogor
}

\author{
(IDENTIFICATION OF ANTIBIOTIC RESISTANT ESCHERICHIA COLI ON BURGER \\ MEATS SOLD AROUND IPB UNIVERSITY AT DRAMAGA BOGOR)
}

\author{
Kumala Andri Asari' ${ }^{1}$, Denny Widaya Lukman², \\ Trioso Purnawarman ${ }^{2}$
}

\author{
${ }^{1}$ Mahasiswa Pascasarjana Program Studi Kesehatan Masyarakat Veteriner, \\ ${ }^{2}$ Divisi Kesehatan Masyarakat Veteriner dan Epidemiologi, \\ Departemen Ilmu Penyakit Hewan dan Kesehatan Masyarakat Veteriner \\ Fakultas Kedokteran Hewan, Institut Pertanian Bogor \\ Jl. Agatis Kampus IPB Dramaga, Bogor, Jawa Barat, Indonesia 16680 \\ Telepon/Faksimili: 0251-8628811; Email: kumala180582@gmail.com
}

\begin{abstract}
This study aimed to determine the occurrence of antibiotic-resistant Escherichia coli (E. coli) isolated from burger meats sold within the radius of $2 \mathrm{~km}$ around the border of IPB University at Dramaga-Bogor, Indonesia. A total of 35 burger meat samples were taken from all burger sellers ( 7 sellers). Isolation and identification of $E$. coli were carried out based on the method in the Indonesian National Standard Number 2897 (2008). The resistance against eleven antibiotics (ampicillin, amoxicillin, streptomycin, oxytetracycline, tetracycline- cefotaxime, gentamicin, enrofloxacin, nalidixic acid, chloramphenicol, and trimethoprim-sulfamethoxazole were tested using Kirby-Bauer method based on the standard of Clinical Laboratory Standards Institute in 2018. The data were analyzed descriptively. The result showed that $11.4 \%$ samples ( 4 of 35 samples). There were 5 isolates of $E$. coli that were isolated from 4 samples and they were all resistant to streptomycin (100\%), gentamicin (80\%), ampicillin, nalidixic acid, trimethoprimsulfamethoxazole (60\%) and amoxicillin, enrofloxacin oxytetracycline (40\%), and tetracycline (20\%). There were $80 \%$ of $E$. coli isolates also resistant to more three classes of antibiotics which were known as multidrug resistant (MDR) with the pattern of AMP-AMC-S-CN (ampicillin-amoxicillin-streptomycingentamicin), AMP-S-ENR-NA-SXT-CN (ampicillin-streptomycin-enrofloxacin-nalidixicacid-trimethoprim sulfamethoxazole-gentamicin), AMP-S-ENR-NA-SXT-OT-CN (ampicillin-streptomycin-enrofloxacinnalidixic acid-trimethoprim sulfamethoxazole-oxytetracycline-gentamicin), and AMC-TE-S-NA-SXT-OT$\mathrm{CN}$ (amoxicillin-tetracycline-streptomycin-nalidixic acid-trimethoprim-sulfamethoxazole- oxytetracyclinegentamicin). Occurance of antibiotic-resistant $E$. coli in burger meat as ready-to-eat food can bring a health risk for the consumer.
\end{abstract}

Keywords: antibiotic-resistant; E. coli; multi-drug resistant; burger meat

\begin{abstract}
ABSTRAK
Penelitian ini bertujuan untuk mengetahui cemaran Escherichia coli dan resistansinya terhadap antibiotik pada sampel daging burger yang dijual pada radius $2 \mathrm{~km}$ batas Kampus Institut Pertanian Bogor di Dramaga, Bogor. Sebanyak 35 sampel daging burger diperoleh dari semua pedagang burger (tujuh pedagang). Isolasi dan identifikasi E. coli mengacu pada Standar Nasional Indonesia 2897:2008. Uji resistansi terhadap antibiotik menggunakan metode Kirby-Bauer dengan acuan dari Clinical Laboratory Standards Institute tahun 2018. Uji resistansi antibiotik dilakukan terhadap semua isolat $E$. coli yang didapat dari semua koloni $E$. coli yang diisolasi dari sampel daging burger. Antibiotik yang digunakan dalam penelitian ini adalah ampisilin, amoksisilin, streptomisin, oksitetrasiklin, tetrasiklin, sefotaksim, gentamisin, enrofloksasin, asam nalidiksat, kloramfenikol, dan trimetoprim-sulfametoksasol. Data dianalisis secara deskriptif. Hasil pengujian menunjukkan11,4\% (4 dari 35 sampel) positif $E$. coli. Isolat yang diperoleh dari empat sampel ada lima isolat $E$. coli (100\%) yang resistan terhadap antibiotik
\end{abstract}


yang diuji. Resistansi tertinggi ditemukan pada antibiotik streptomisin (100\%) dan gentamisin (80\%). Dari lima isolat $E$. coli yang didapat, empat isolat di antaranya telah resistan terhadap tiga atau lebih golongan antibiotik yang dikenal sebagai multi-drug resistant (MDR), dengan pola resistansi yang terdiri atas AMP-AMC-S-CN (ampisilin-amoksisilin-streptomisin-gentamisin), AMP-S-ENR-NA-SXT-CN (ampisilin-streptomisin-enrofloksasin-asam nalidiksat-trimetoprim sulfametoksasol-gentamisin), dan AMP-S-ENR-NA-SXT-OT-CN (ampisilin-streptomisin- enrofloksasin-asam nalidiksat- trimetoprim sulfametoksasol-oksitetrasikilin-gentamisin). Keberadaan $E$. coli resistan pada daging burger yang termasuk pangan siap santap (ready-to-eat food) dapat menimbulkan risiko kesehatan pada konsumen.

Kata-kata kunci: Escherichia coli; resistan antibiotik; multi-drug resistant; daging burger

\section{PENDAHULUAN}

Pangan merupakan kebutuhan dasar manusia yang paling utama. Penyakit dapat disebarkan melalui makanan dan disebut penyakit bawaan makanan (foodborne disease). Beberapa agen penyakit yang paling sering menyebabkan foodborne disease adalah Salmonella sp., Clostridium sp. dan Escherichia coli. E. coli dapat masuk ke dalam tubuh manusia terutama melalui konsumsi pangan yang tercemar, misalnya daging mentah, daging yang dimasak setengah matang, susu mentah, serta cemaran fekal pada air dan pangan (Ademi dan Rinanda, 2011).

Burger merupakan salah satu makanan siap santap (ready-to-eat food/RTE) yang saat ini banyak dikonsumsi dan termasuk makanan yang cocok dengan selera lidah masyarakat Indonesia. Burger merupakan makanan sejenis sandwich yang berasal dari Hamburg, Jerman. Burger terdiri atas roti yang berisi daging dan sayuran seperti irisan tomat, timun, dan selada, serta ditambah saus dan mayonnaise. Daging burger terbuat dari daging segar yang digiling, kemudian ditambahkan bumbu-bumbu, biasanya berbentuk gepeng setebal satu $\mathrm{cm}$ (Lumbong et al., 2017). Bagi mahasiswa Institut Pertanian Bogor (IPB), burger biasanya diperoleh dari pedagang makanan jajanan kaki lima yang tersebar di sekitar Kampus IPB Dramaga. Makanan ini biasanya dijual dengan menggunakan gerobak dorong atau meja tenda dan dijajakan di pinggir jalan.

Menurut Ginting et al. (2005) perkembangan makanan RTE yang sangat cepat, seperti burger, yang banyak dikonsumsi oleh masyarakat menyebabkan penjual burger tidak lagi memerhatikan keamanan daging burger. Hal ini dapat dilihat dari segi pengolahan dan penyajian yang kurang higienis. Selain itu, lokasi penjualan burger dalam suatu penelitian yang dilakukan di sekitar kampus Universitas Sumatera Utara (USU) Medan, Sumatera Utara umumnya terletak di pinggir jalan dan berdekatan dengan parit atau selokan.

Kebiasaan mengonsumsi makanan RTE dapat meningkatkan risiko terjadinya foodborne disease. Salah satu bakteri penyebab foodborne disease adalah $E$. coli. Penanganan infeksi karena $E$. coli dapat diobati dengan pemberian antibiotik. Walaupun penanganan infeksi telah menggunakan antibiotik yang direkomendasikan oleh dokter, akan tetapi pada kenyataannya jumlah kasus kejadian penyakit infeksi ada kecenderungan semakin meningkat. Hal ini dapat disebabkan oleh beberapa hal, selain masalah sanitasi, penyebab lain adalah kemungkinan telah terjadinya resistansi bakteri penyebab infeksi terhadap antibiotik (Sasongko 2014).

Resistansi antibiotik merupakan kemampuan mikroorganisme (seperti bakteri, virus, maupun parasit) untuk menghentikan antimikrob (seperti antibiotik, antivirus, antiparasit) yang bekerja melawannya. Hal ini mengakibatkan perawatan standar menjadi tidak efektif, infeksi terus berlanjut, dapat menyebar ke orang lain (WHO 2018).

Keberadaan bakteri yang resistan antibiotik dalam produk pangan perlu menjadi perhatian masyarakat karena berpotensi memindahkan bakteri yang resistan antibiotik ke manusia. Selain itu, bakteri resistan antibiotik dapat menjadi reservoir gen resistan yang dapat dipindahkan ke bakteri patogen atau komensal di saluran pencernaan manusia (ÁlvarezFernández et al., 2013). Manusia kemungkinan mendapatkan infeksi bakteri resistan pada saat menangani atau mengonsumsi daging mentah atau kurang matang atau produk yang terkontaminasi bakteri resistan, di samping itu, manusia juga dapat terinfeksi karena kontak dengan feses hewan, baik melalui kontak langsung dengan hewan dan lingkungan, serta melalui air minum maupun air yang terkontaminasi (CDC, 2018).

Keberadaan E. coli pada daging burger 
dapat menjadi masalah kesehatan masyarakat yang serius apabila tidak ditangani dengan benar dalam proses pengolahan maupun penyajiannya. Selain itu, E. coli juga diduga telah banyak mengalami kejadian resistansi antibiotik yang menyebabkan pengobatan menjadi tidak efektif. Mengingat bahaya penyakit yang ditimbulkan akibat cemaran $E$. coli dengan kemungkinan sifat resistansinya terhadap antibiotik, maka perlu dilakukan penelitian mengenai $E$. coli resistan antibiotik pada daging burger.

Penelitian ini bertujuan untuk mengetahui tingkat resistansi antibiotik bakteri $E$. coli yang diisolasi dari daging burger yang dijual di sekitar Kampus IPB Dramaga, Bogor. Hasil penelitian ini diharapkan dapat menjadi bahan masukan bagi instansi terkait dalam menetapkan kebijakan dalam rangka pencegahan foodbone disease sekaligus sebagai informasi dalam merumuskan program pengendalian resistansi antibiotik.

\section{METODE PENELITIAN}

Bahan yang digunakan dalam penelitian adalah daging burger, buffered peptone water (BPW) 0.1\% (Oxoid CM1049, England), lauryl sulphate tryptose broth (LSTB) (Oxoid CM0451, England), Escherichia coli broth (EC broth) (Oxoid CM0853, England), eosin methylene blue agar (Levine) (LEMB) (Oxoid CM0069, England), methyl red-Voges Proskauer(MR-VP) medium (Oxoid CM0043, England), SIM medium (Oxoid CM0435, England), koser citrate broth (Conda Cat 1200 00, Spain), Kovacs indole reagent (Merck 109293 0100, Germany), nutrient agar (NA) (Oxoid CM0003, England), $\mathrm{KOH} \mathrm{40 \% ,}$ Mueller Hinton agar (MHA) (Oxoid CM0337, England), tryptone soya broth (TSB) (Oxoid CM0129, England), E. coli American Type Culture Collection (ATCC) 25922 (Thermo), disk antibiotik: ampisilin (AMP) $10 \mu \mathrm{g}$ (Oxoid AMP 10 CT0003B, England), amoksisilin (AMC) 30 $\mu \mathrm{g}$ (Oxoid AMC 30 CT0223B, England), trimetoprim-sulfametoksasol (SXT) $25 \mu \mathrm{g}$ (Oxoid SXT 25 CT0052B, England), tetrasiklin (TE) 30 $\mu \mathrm{g}$ (Oxoid TE 30 CT0054B, England), oksitetrasiklin (OT) $30 \mu \mathrm{g}$ (Oxoid OT 30 CT0041B, England), gentamisin (CN) $10 \mu \mathrm{g}$ (Oxoid CN 10 CT0024B, England), streptomisin (S) $10 \mu \mathrm{g}$, kloramfenikol (CL) $30 \mu \mathrm{g}$ (Oxoid CL 30 CT0013B, England), sefotaksim (CTX) $30 \mu \mathrm{g}$ (Oxoid CTX 30 CT0166B, England), asam nalidiksat (NA) $30 \mu \mathrm{g}$ (Oxoid NA 30 CT0031B, England), dan enrofloksasin (ENR) $5 \mu \mathrm{g}$ (Oxoid ENR 5 CT639B, England).

Alat yang digunakan antara lain plastik steril, botol media, gunting, pinset, gelas ukur, cawan petri, tabung reaksi, tabung dlurham, sumbat tabung dan rak tabung reaksi, labu erlenmeyer, mikropipet, batang ose, stomacher, bunsen, timbangan digital, penangas air, inkubator, autoklaf, cooler box, ice pack, lemari pendingin (refrigerator), dan freezer.

\section{Pengambilan Sampel}

Penelitian ini dilaksanakan pada bulan September 2019 sampai dengan Januari 2020. Pengujian dilakukan di Laboratorium Kesehatan Masyarakat Veteriner (Kesmavet), Divisi Kesehatan Masyarakat Veteriner dan Epidemiologi, Departemen Ilmu Penyakit Hewan dan Kesehatan Masyarakat Veteriner, Fakultas Kedokteran Hewan (FKH), Institut Pertanian Bogor, Dramaga, Bogor.

Sebanyak 35 sampel daging burger diperoleh dari seluruh pedagang burger (total 7 pedagang) yang berjualan pada radius $2 \mathrm{~km}$ di sekitar Kampus IPB, Dramaga, Bogor dengan ulangan sebanyak lima kali pada hari yang berbeda. Pengambilan sampel dimulai dari pukul 19.0021.00 WIB. Burger yang dibeli hanya bagian roti dan daging burger saja, tanpa penambahan sayuran dan saus. Sampel daging burger diambil secara aseptis, dimasukkan ke dalam plastik steril, kemudian disimpan di dalam cooler box berisi ice pack pada suhu $4-7{ }^{\circ} \mathrm{C}$. Selanjutnya sampel disimpan di refrigerator pada suhu $1-4{ }^{\circ} \mathrm{C}$ untuk diuji keesokannya. Pengujian isolasi dan identifikasi dilakukan dalam waktu tidak lebih dari 24 jam setelah pengambilan sampel.

\section{Isolasi dan Identifikasi E. coli}

Pengujian laboratorium terhadap E. coli pada sampel daging burger mengacu pada SNI 2897:2008 (BSN, 2008). Bakteri E. coli ATCC 25922 digunakan sebagai kontrol positif dalam setiap pengujian. Sampel daging burger ditimbang sebanyak $25 \mathrm{~g}$ kemudian ditambah dengan $225 \mathrm{~mL}$ BPW 0,1\%, setelah itu dihomogenkan menggunakan stomacher selama 1 menit. Sampel yang telah homogen lalu dipindahkan sebanyak $1 \mathrm{~mL}$ ke tabung LSTB dan diinkubasi pada suhu $35^{\circ} \mathrm{C}$ selama $48 \pm 2$ jam. Biakan positif ditandai dengan adanya gas yang terbentuk pada tabung Durham, selanjutnya dipindahkan $1 \mathrm{~mL}$ ke dalam tabung 
EC broth dan diinkubasi pada suhu $45,5{ }^{\circ} \mathrm{C}$ selama $48 \pm 2$ jam. Hasil yang positif pada EC broth lalu diinokulasikan ke media selektif LEMB, selanjutnya diinkubasi selama 18-24 jam pada suhu $35^{\circ} \mathrm{C}$. Koloni yang diduga $E$. coli pada media LEMB berwarna hitam/gelap dengan bagian pusat koloni berwarna hijau metalik. Koloni yang diduga $E$. coli dibiakkan pada media NA dan diinkubasi pada suhu $35^{\circ} \mathrm{C}$ selama 18 24 jam. Isolat dari NA kemudian diuji menggunakan uji biokimia indol, methyl red, Voges Proskauer, dan citrate (IMViC) untuk konfirmasi. Klasifikasi $E$. coli pada reaksi IMViC ditunjukkan dengan pola + + - - atau - + - -, dan uji indole menunjukkan hasil positif atau negatif, uji methyl red positif, uji Voges Proskauer negatif, serta uji citrate menunjukkan hasil negatif.

Pengujian Resistansi terhadap Antibiotik

Pengujian resistansi $E$. coli terhadap antibiotik pada sampel daging burger menggunakan metode difusi cakram (disk diffusion) Kirby-Bauer pada media MHA(CLSI 2018). Uji resistansi terhadap antibiotik dilakukan terhadap semua koloni $E$. coli yang diisolasi dari sampel daging burger. Cakram kosong tanpa antibiotik digunakan sebagai kontrol negatif dalam setiap uji. Isolat $E$. coli disiapkan dalam bentuk suspensi dalam media tryptone soya broth (TSB) yang setara dengan

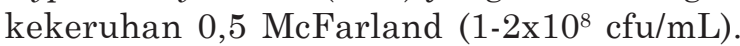
Biakan tersebut kemudian diambil dengan menggunakan cotton swab steril dan disebarkan pada permukaan MHA, lalu didiamkan selama \pm 5 menit. Selanjutnya dengan metode Kirby-Bauer, kertas cakram komersial yang berisi antibiotik diletakkan di atas MHA yang telah disebar dengan biakan murni dengan jarak 25-30 mm. Selanjutnya biakan tersebut diinkubasi pada suhu $35^{\circ} \mathrm{C}$ selama 16 - 18 jam.

Berdasarkan CLSI (2018) dan menurut studi resistansi $E$. coli terhadap antibiotik sebelumnya yang ditemukan pada manusia dan produk hewan (Lei et al., 2010; Tadesseet al., 2012; Poirel et al., 2018), maka antibiotik yang digunakan dalam penelitian ini adalah ampisilin (golongan penisilin), amoksisilin (golongan beta laktam/kombinasi inhibitor beta-laktamase, trimetoprim-sulfametoksasol (golongan sulfonamid), oksitetrasiklin, tetrasiklin (golongan tetrasiklin), streptomisin, gentamisin (golongan aminoglikosida), kloramfenikol golongan fenikol), sefotaksim (golongan sefalosporin), asam nalidiksat (golongan kuinolon), dan enrofloksasin (golongan florokuinolon). Data yang diperoleh dari hasil pengujian di laboratorium dianalisis secara deskriptif dan disajikan dalam bentuk grafik.

\section{HASIL DAN PEMBAHASAN}

\section{Escherichia coli pada Daging Burger}

Hasil pengujian laboratorium menunjukkan empat dari 35 sampel $(11,4 \%)$ daging burger positif mengandung E. coli (Gambar 1). Dari empat sampel yang positif $E$. coli diperolah lima isolat $E$. coli yang tumbuh pada agar EMB. Hasil penelitian ini lebih rendah dibandingkan dengan penelitian yang dilakukan oleh Ginting et al. (2005) yang mendapatkan 20\% sampel daging burger yang dijual di sekitar kampus USU di Medan tercemar bakteri $E$. coli dan penelitian oleh Ademi dan Rinanda (2011) yang mendapatkan lebih dari 50\% sampel daging burger yang dijual di pedagang kaki lima maupun restoran cepat saji di Desa Kopelma Darussalam, Banda Aceh tercemar bakteri $E$. coli. Hasil penelitian ini juga lebih rendah jika dibandingkan dengan penelitian yang dilakukan oleh Amani et al. (2017) yang menyatakan bahwa sebanyak 20\% beef burger yang dijual di beberapa supermarket di Menoufia, Mesir tercemar oleh bakteri E. coli. Apabila dibandingkan dengan penelitian Abdel-Rhman et al. (2015) yang mendapatkan 10\% daging segar, daging giling, dan daging burger yang dijual di beberapa supermarket dan toko daging di Mesir tercemar bakteri $E$. coli, maka persentase keberadaan $E$. coli pada penelitian ini lebih tinggi.

Keberadaan E. coli pada daging burger yang dijual di sekitar Kampus IPB Dramaga Bogor

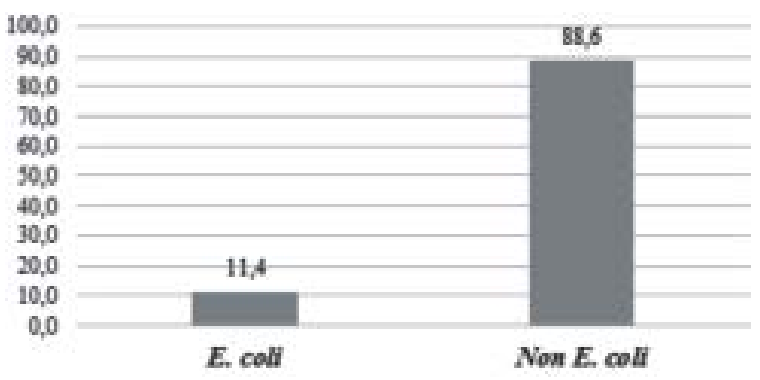

Gambar 1. Persentase prevalensi Escherichia coli dan non E. coli pada daging burger yang dijual di sekitar Kampus IPB di Dramaga Bogor 
menunjukkan adanya cemaran E. coli pada daging burger. Hal ini dapat disebabkan oleh berbagai faktor antara lain asal daging, proses pengolahan, proses penanganan makanan, peralatan yang kurang higienis, serta penerapan sanitasi dan higiene personal yang kurang baik. Variasi hasil yang berbeda antara peneliti kemungkinan disebabkan oleh perbedaan dalam praktik pengolahan, penanganan dari produsen ke konsumen, serta penerapan higiene sanitasi selama produksi. Keberadaan E. coli dalam makanan dianggap sebagai indikator penyimpangan atau kesalahan selama persiapan, pengolahan, penyimpanan, serta penyajian makanan (Shaltout et al., 2016). Menurut Ademi dan Rinanda (2011), pencemaran makanan oleh $E$. coli tidak terlepas dari alur atau proses pengelolaan makanan mulai dari pemilihan dan penyimpanan bahan makanan sampai dengan pengolahan, penyimpanan, pengangkutan, serta penyajian makanan.

\section{Escherichia coli Resistan Antibiotik}

Sebanyak lima isolat E. coli dilakukan pengujian resistansi antibiotik dengan menggunakan metode difusi cakram KirbyBauer untuk menentukan profil resistan yang dimiliki oleh 11 antibiotik yang terdiri atas sembilan golongan antibiotik. Pada penelitian ini seluruh isolat (100\%) telah resistan terhadap antibiotik. Hasil uji resistansi sebagaimana pada Gambar 2 menunjukkan tingkat resistansi yang tinggi ditemukan pada antibiotik streptomisin (100\%) dan gentamisin (80\%). Selain itu ditemukan beberapa antibiotik yang berpotensi menjadi resistansi tinggi seperti ampisilin, asam nalidiksat, dan trimetoprimsulfametoksasol (60\%), amoksisilin, enrofloksasin, oksitetrasiklin (40\%), dan tetrasiklin (20\%) sehingga perlu diwaspadai karena ada kecenderungan meningkat pada waktu yang akan datang. Kondisi tersebut dapat berpotensi menjadi ancaman di masa yang akan datang

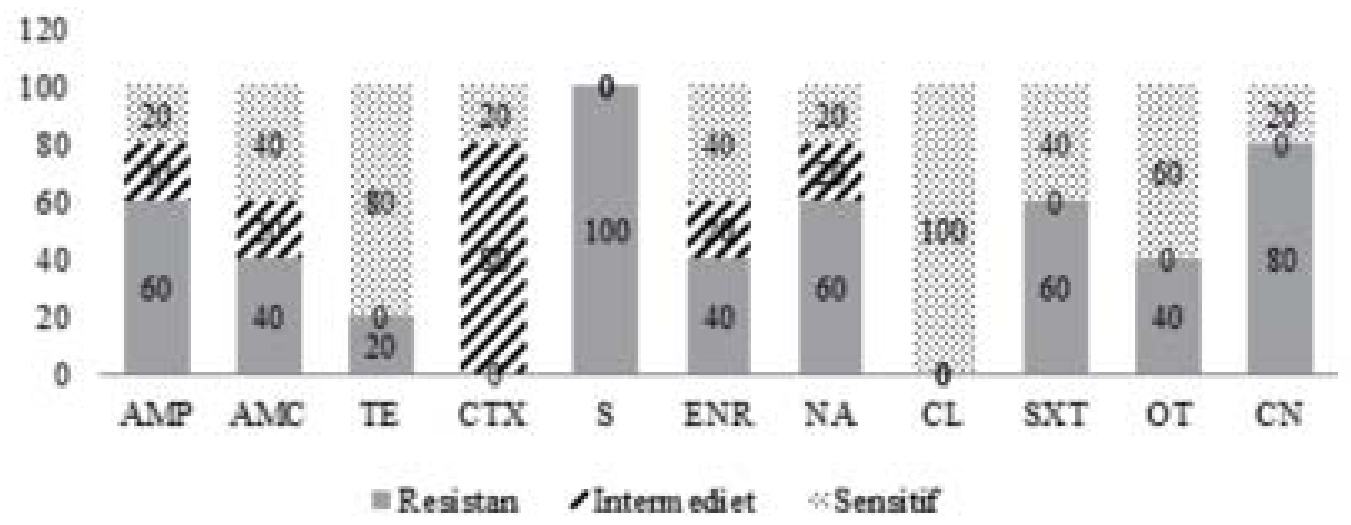

Gambar 2. Persentase Escherichia coli sensitif, intermediet, dan resistan pada sampel daging burger yang dijual di sekitar Kampus IPB Dramaga Bogor: ampisilin (AMP10), amoksisilin (AMC30), tetrasiklin (TE30), sefotaksim (CTX30), streptomisin (S10), enrofloksasin (ENR5), asam nalidiksat (NA30), kloramfenikol (CL30), trimetoprim-sulfametoksasol (SXT25), oksitetrasiklin (OT30), dan gentamisin (CN10)

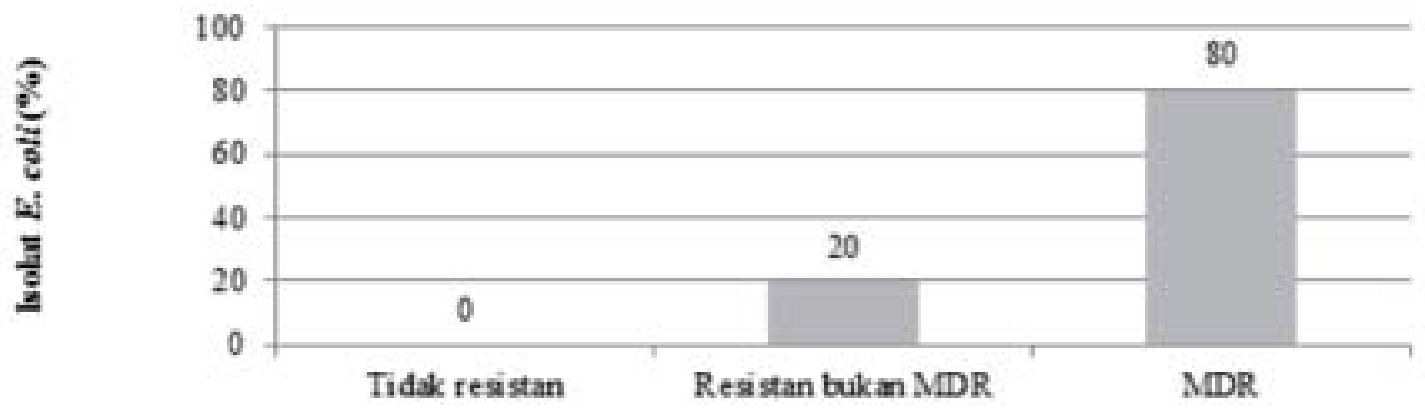

Gambar 3. Persentase prevalensi multi-drug resistant (MDR) Escherichia coli dan non MDR pada sampel daging burger yang dijual di sekitar Kampus IPB di Dramaga Bogor 
apabila pemakaian antibiotik tidak dikendalikan.

Hasil penelitian ini serupa dengan penelitian Lei et al. (2010) yang menemukan bahwa isolat $E$. coli dari produk makanan asal hewan menunjukkan tingkat resistansi sebesar $64 \%$ pada antibiotik ampisilin dan $68 \%$ pada antibiotik trimetoprim-sulfametoksasol. Hasil penelitian ini berbeda dengan penelitian Magwira et al. (2005) yang menemukan semua isolat E. coli yang diisolasi dari produk daging sapi/sampel daging giling yang dijual di tingkat pengecer (distributor) di Gaborone, Bostwana sensitif terhadap ampisilin dan gentamisin. Selain itu, beberapa isolat $E$. coli juga resistan terhadap beberapa antibiotik seperti kolistin sulfat (26\%), tetrasiklin (26\%), dan streptomisin $(0.7 \%)$.

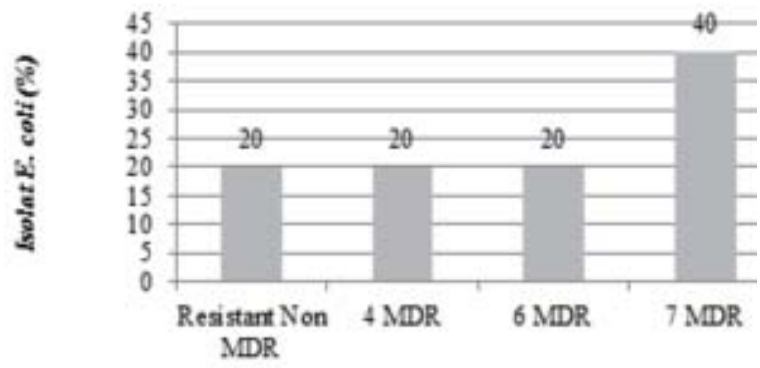

Gambar 4. Persentase prevalensi multi-drug resistant (MDR) Escherichia coli pada sampel daging burger yang dijual di sekitar Kampus IPB di Dramaga Bogor

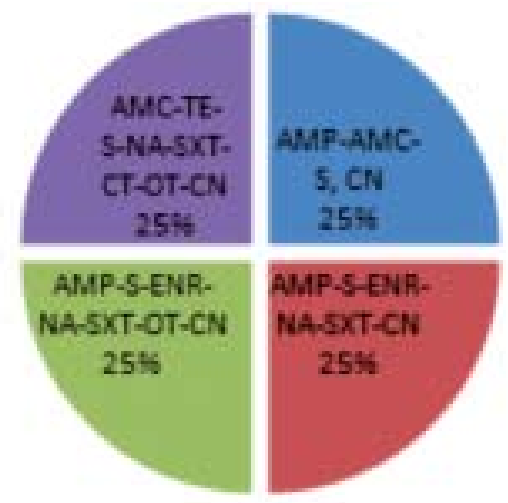

Gambar 5. Pola multi-drug resistant (MDR) Escherichia coli pada sampel daging burger yang dijual di sekitar Kampu IPB di Dramaga Bogor: ampisilin (AMP10), amoksisilin (AMC30), tetrasiklin (TE30), sefotaksim (CTX30), streptomisin (S10), enrofloksasin (ENR5), asam nalidiksat (NA30), kloramfenikol (C30), trimetoprim-sulfametoksasol (SXT25), oksitetrasiklin (OT30), dan gentamisin (CN10).
Resistansi antibiotik dapat dipicu karena mengonsumsi pangan asal hewan yang mengandung residu antibiotik. Selain itu juga dapat disebabkan oleh adanya bakteri patogen dari hewan sakit yang ikut terbawa dalam pangan asal hewan (Pesavento et al., 2007). Resistansi yang muncul dapat disebabkan oleh berbagai faktor risiko seperti penggunaan antibiotik yang tidak tepat pada hewan maupun manusia, baik untuk pencegahan maupun untuk pengobatan penyakit. Selain itu, penggunaan antibiotik sebagai imbuhan pakan pada ternak (feed additive) yang digunakan terus menerus akan meningkatkan galur bakteri yang resistan terhadap antibiotik. Salah satu dampak dari peningkatan galur bakteri yang resistan terhadap antibiotik pada ternak yaitu dapat mengakibatkan kegagalan pengobatan pada hewan dan manusia (Krisnaningsih 2005; Kusumaningsih 2012).

Penelitian ini mendapatkan pula bahwa seluruh isolat $E$. coli sensitif terhadap kloramfenikol. Hal ini sejalan dengan penelitian Hiko et al. (2008) yang menemukan bahwa seluruh isolat $E$. coli yang diisolasi dari sampel daging sapi mentah yang dijual di tingkat pengecer di Ethiopia sensitif terhadap kloramfenikol.

\section{Multi-Drug Resistant (MDR) E. coli}

Prevalensi MDR E. coli pada sampel daging burger pada penelitian ini menunjukkan persentase tinggi. Dari hasil penelitian diperoleh sebesar 80\% (4/5) isolat E. coli menunjukkan MDR terhadap antibiotik yang diuji (Gambar 3 ). Isolat $E$. coli yang diuji menunjukkan adanya MDR yang bervariasi yaitu adanya isolat yang multiresistan terhadap 4, 6 , dan 7 jenis antibiotik sebagaimana Gambar 4.

Istilah MDR adalah untuk menerangkan adanya resistansi bakteri terhadap tiga atau lebih golongan antibiotik (Magiorakos et al., 2012). Bakteri menjadi MDR disebabkan oleh akumulasi beberapa gen pada plasmid $R$ yang masing-masing menyandi sifat resistan terhadap satu antibiotik dalam sel tunggal atau akibat dari peningkatan ekspresi gen yang menyandi pompa efflux (Nikaido 2009). Pola resistansi MDR yang ditemukan dalam penelitian ini ada sebanyak empat isolat dengan empat pola resistansi yang terdiri atas: AMPAMC-S-CN (ampisilin-amoksisilin-streptomisingentamisin), AMP-S-ENR-NA-SXT-CN (ampisilin-streptomisin-enrofloksasin-asam nalidiksat-trimetoprim sulfametoksasol- 
gentamisin), AMP-S-ENR-NA-SXT-OT-CN (ampisilin-streptomisin-enrofloksasin-asam nalidiksat-trimetoprim sulfametoksasoloksitetrasikilin-gentamisin), dan pola AMC-TES-NA-SXT-OT-CN (amoksisilin-tetrasiklinstreptomisin- asam nalidiksat-trimetoprim sulfametoksasol-oksitetrasiklin-gentamisin) (Gambar 5).

Resistansi terhadap antibiotik streptomisin (S) dan ampisilin (AMP) mendominasi dalam kemunculan pola resistansi MDR E. coli pada sampel daging burger. Sifat MDR oleh bakteri terhadap antibiotik, termasuk golongan âlaktam, streptomisin, dan derivat tetrasiklin sering ditemukan dalam kasus resistansi bakteri terhadap antibiotik, khususnya $E$. coli dan Salmonella sp. (Krisnaningsih 2005).

\section{SIMPULAN}

Keberadaan E. coli pada daging burger yang dijual di sekitar Kampus IPB Dramaga, Bogor cukup tinggi $(11,4 \%)$. Semua isolat $E$. coli yang diuji memiliki sifat resistansi terhadap suatu antibiotik dan $80 \%$ isolat $E$. coli memiliki sifat MDR.

\section{SARAN}

Penelitian lebih lanjut perlu dilakukan guna mengidentifikasi galur E. coli dan uji identifikasi gen penyandi resistansi. Selain itu perlu dilakukan pembinaan kepada para pedagang kaki lima oleh instansi terkait dalam rangka pencegahan foodborne disease, serta pemantauan dan surveilans resistansi antibiotik secara rutin, utamanya pada produk pangan asal hewan dalam rangka merumuskan program pengendalian resistansi antibiotik.

\section{UCAPAN TERIMA KASIH}

Terima kasih diucapkan kepada Kementerian Pertanian yang telah mendanai penelitian ini serta kepada seluruh staf Laboratorium Kesehatan Masyarakat Veteriner, FKH, IPB, Dramaga, Bogor yang telah membantu selama proses penelitian.

\section{DAFTAR PUSTAKA}

Abdel-Rhman SH, Khalifa SM, Abd El Galil KH, Barwa RM. 2015. Prevalence of toxins and antimicrobial resistance among $E$. coli isolated from meat. AiM 5: 737-747.

Ademi BF, Rinanda T. 2011. Deteksi cemaran Escherichia coli pada daging burger penjual kaki lima di Desa Kopelma Darussalam dan restoran cepat saji di Banda Aceh. Jurnal Kedokteran Syiah Kuala 3: 134-142.

Álvarez-Fernández E, Cancelo A, Díaz-Vega C, Capita R, Alonso-Calleja C. 2013. Antimicrobial resistance in $E$. coli isolates from conventionally and organically reared poultry: A comparison of agar 11 disc diffusion and Sensi Test Gram-negative methods. Food Cont 30: 227-234.

Amani MS, Shaimaa MN, Mohamed AK. 2017. Challenge of multi drug resistant stx 1 harboring E. coli in meat and fast foods. British Veterinary Medical Journal 33(2): 117-128.

[BSN] Badan Standardisasi Nasional. 2008. SNI No. 2897:2008 tentang Metode Pengujian Cemaran Mikroba dalam Daging, Telur dan Susu, serta Hasil Olahannya. Jakarta. BSN.

[CDC] Centers for Disease Control and Prevention. 2018. Antibiotic resistance, food and food producing animal. http:// www.cdc.gov/features/antibiotic resistancefood/index.html. [26 Mei 2019]

[CLSI] Clinical and Laboratory Standards Institute. 2018. M100S- Performance Standards for Antimicrobial Susceptibiliy Testing. Ed ke-28. Wayne. CLSI.

Ginting WNP, Santi DN, Chahaya I. 2005. Hygiene Sanitasi dan Analisa Pencemaran Salmonella Sp. pada Daging Sapi Olahan (Daging Burger) Sebelum danSesudah Digoreng yang idjual di Kelurahan Helvetia Timur Kecamatan Medan Helvetia Kota Medan Tahun 2013. https://www.google. com/search?client=firefox-bd\&q=Ginting + +EP.+2005.+Kandungan+bakteri+ Escherichia+ coli+ dan+Salmonella+ sp.+pada+dagin g+burger+yang+dijual+ di+sekitar+kam pus+USU+Medan+\%5Bs kripsi\%5D.+Medan+\%28ID\% 29\%3A+ Universitas+Sumatera+Utara. 
Hiko A, Asrat D, Zewdw G. 2008. Occurrence of EscherichiacoliO157: $\mathrm{H} 7$ in retail raw meat products in Ethiopia. J Infect Dev Countries 2(5): 389-393.

Krisnaningsih MMF, Asmara W, Wibowo MH. 2005. Uji sensitivitas isolat Escherichia coli patogen pada ayam terhadap beberapa jenis antibiotik. Jurnal Sains Veteriner 1: 13-18.

Kusumaningsih A. 2012. Faktor pemicu foodborne diseases asal ternak. Wartazoa. 22(3): 107-112.

Lei T, Tan W, Huang XH, Sun YX, Deng YT, Sun Y, Hong D, Wu CM, Huang LZ,

Shen JZ, Liu JH. 2010. Antimicrobial resistance in Escherichia coli isolates from food animals, animal food products and companion animals in China. Vet Microbiol 146: 85-89.

Lumbong R, Tinangon RM, Rotinsulu MD, Kalele JAD. 2017. Sifat organoleptik burger ayam dengan dengan metode memasak yang berbeda. J Zootek 37(2): 252-258.

Magiorakos AP, Srinivasan A, Carey RB, Carmeli Y, Falagas ME, Giske CG, Harbath S, Hindler JF, Kahlmeter G, OlssonLilijequist B, Paterson DL, Rice LB, Stelling J, Struelonss MJ, Vatopoulos A, Weber JT, Monnet DL. 2012. Multidrug-resistant, extensively drug-resistant and pandrugresistant bacteria. Clin Microbiol Infect 18: 268-281.

Magwira CA, Gashe BA, Collison EK. 2005. Prevalence and antibiotic resistance profiles of Escherichia coli O157:H7 in beef products from retail outlets in Gaborone, Botswana. J Food Prot 68(2): 403-406.
Nikaido H. 2009. Multidrug resistance in bacteria. Annu Rev Biochem 78: 119-146.

Pesavento G. Ducci B, Comodo N, Nostro AL. 2007. Antimicrobial resistance profile of Staphylococcus aureus isolated from raw meat: a research for methicillin resistant Staphylococcus aureus (MRSA). Food Cont 18: 196-200.

Poirel L, Madec JY, Lupo A, Schink AK, Kieffer N, Nordman P, Schwarz S. 2018. Antimicrobial resistance in Escherichia coli. Microbiol Spect 6(4): 1-27.

Sasongko H. 2014. Uji resistensi bakteri Escherichia coli dari sungai boyong Kabupaten Sleman terhadap antibiotik amoksisilin, kloramfenikol, sulfametoxasol, dan streptomisin. J Bioedukatika 2(1): 2529.

Shaltout FA, Salem AM, Khater DF, Lela RA. 2016. Studies on bacteriological profile of some meat products. British Veterinary Medical Journal 31(1): 43-49.

Tadesse DA, Zhao S, Tong E, Ayers S, Singh A, Bartholomew MJ, McDermott PF.2012. Antimicrobial drug resistance in Escherichia coli from humans and food animals, United States, 1950-2002. Emerg Inf Dis 18(5): 741749 .

[WHO] World Health Organization. 2018. Antimicrobial resistance. [2019 Jul 18]. http://www.who.int/en/news-room/factsheets/detail/antimicrobial-resistance. [18 Juli 2019]. 